\title{
Barn med krumme legger
}
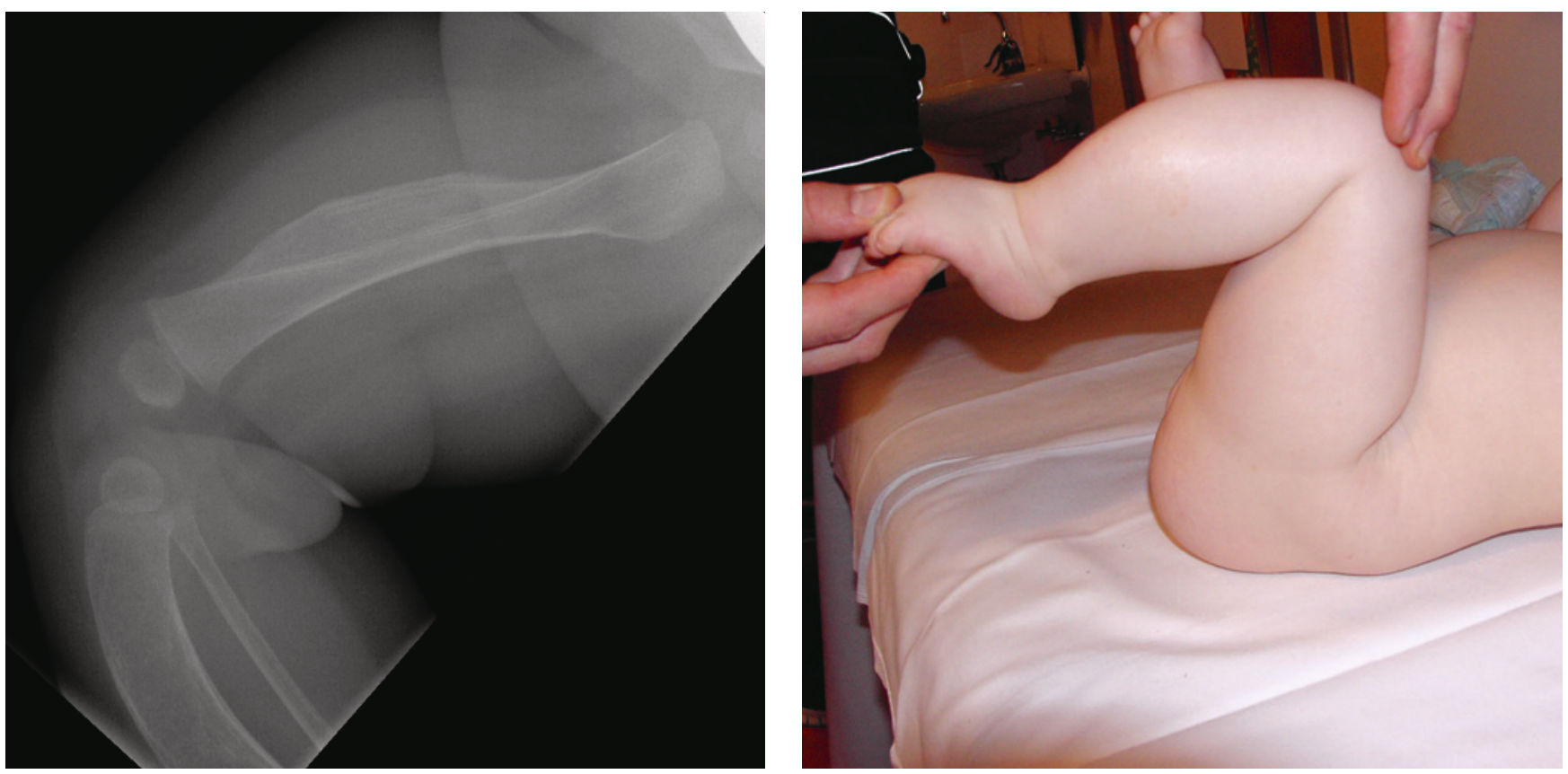

En tre måneder gammel jente ble henvist med spørsmål om tumor på låret. Barneradiolog fant ved ultralydundersøkelse distinkt ømhet og bløtvevsødem foran på høyre lår, men ingen bløtdelstumor. Supplerende røntgenundersøkelse viste fortykkelse av corticalis (kortikal hyperosteose) i høyre femurdiafyse (bildet til venstre), anterior krumming av begge tibiae med brede, oppdrevne diafyser og fortynnet corticalis. Tilsvarende forandringer ble funnet $\mathrm{i}$ høyre femur. Krumningen av tibia ses tydelig på lysbildet til høyre.

Pasientens far og farmor ble født med liknende legger - hos begge var det spontan bedring i løpet av et par år. Røntgenopptak av farens legger viste antydet anterior krumming av begge tibiae, med noe utvisket kortikomedullær grense i diafysene.

Pasienten ble henvist fra den lokale barneavdelingen til nærmeste universitetssykehus.

Sykehistorie og røntgenfunn var forenelig med Caffeys sykdom, infantil kortikal hyperostose, som er karakterisert ved subperiostal beinnydanning som oftest involverer mandibula, de lange rørknoklene, clavicula og ribbein.

Tilstanden debuterer typisk tidlig i spedbarnsperioden med feber, irritabilitet og lokal ømhet på grunn av bløtvevsødem (1). Til- heling skjer spontant i løpet av de to første leveårene. Leukocytose, forhøyet alkalisk fosfatase og forhøyet senkning ses ofte. Sykdommen nedarves autosomalt dominant. Den er en sjelden, men viktig differensialdiagnose til osteomyelitt, malignitet og barnemishandling.

Pasientens far ble testet og funnet å være heterozygot for varianten c.3040C $>\mathrm{T}$ (p.R1014C) i COL1A1-genet, forenlig med Caffeys sykdom. Det ble vurdert som unødvendig også å få utført gensekvensering av pasienten, ettersom man nå hadde en genetisk påvist diagnose som bekreftet en allerede sterk klinisk mistanke.

Pasientens foreldre og pasientens farmor har gitt samtykke til at artikkelen blir publisert.

Vi takker Avdeling for medisinsk genetikk ved Oslo universitetssykehus, som utførte den genetiske undersøkelsen.

\section{Anders Batman Mjelle}

adnj@helse-bergen.no

Pétur Benedikt Júlíusson

Barneklinikken

\section{Stein Magnus Aukland}

Seksjon for barn

Radiologisk avdeling

Haukeland universitetssykehus
Anders Batman Mjelle (f. 1982) er lege i spesialisering i barnesykdommer.

Forfatter har fylt ut ICMJE-skjemaet og oppgir ingen interessekonflikter.

Pétur Benedikt Júlíusson (f. 1964) er spesialist i barnesykdommer, overlege og postdoktor ved Universitetet i Bergen. Han har delt hovedansvar for Skjelettdysplasipoliklinikken.

Forfatter har fylt ut ICMJE-skjemaet og oppgir ingen interessekonflikter.

Stein Magnus Aukland (f. 1967) er radiolog, overlege og førsteamanuensis ved Universitetet i Bergen.

Forfatter har fylt ut ICMJE-skjemaet og oppgir ingen interessekonflikter.

\section{Litteratur}

1. Shandilya R, Gadre KS, Sharma J et al. Infantile cortical hyperostosis (Caffey disease): a case report and review of the literature - where are we after 70 years? J Oral Maxillofac Surg 2013; 71 $1195-201$.

Mottatt 13.9. 2013, første revisjon innsendt 25.12. 2013, godkjent 9.1. 2014. Redaktør: Matilde Risopatron Berg. 